\title{
Investigation of the Mould Resistance Design (MRD) model for mould growth in attics
}

\author{
Thor Hansen ${ }^{1}$ and Petter Wallentén ${ }^{2}$ \\ ${ }^{1}$ Statens Byggeforskningsinstitut (SBi)/AAU, Denmark \\ ${ }^{2}$ Lund University, DP of Building Physics, Box118 22100 Lund, Sweden
}

\begin{abstract}
Based on measurements of mould in 17 attics in the north of Sweden, 3 were chosen as a tentative validation of the MRD-model (Mould Resistance Design) for long periods of time (1961-2012). Comparing the measurements and the results from the simulations showed great differences regarding the mould growth depending on the simplifications used in the model. How the leakage was simulated and where the moisture from the leakage was placed in the construction were the most important factors. The study could not validate the MRD model as such, but it was clear that the simulations with relatively small adjustments could give realistic data
\end{abstract}

\section{Introduction}

There are several models for predicting the mould growth in wood [4]. The models are based on different assumptions and sometimes calibrated against in situ measurements or laboratory measurements. One of these models is the so called MRD-model (Mould Resistance Design), [3-4]. This model is mainly calibrated against laboratory measurements. In 2011 a possibility arose to make destructive investigations of a number of dwellings in the town of Malmberget within Gällivare Municipality in northern Sweden [1], an example can be seen in figure 1. The investigations covered different areas but were mainly focused on determining the moisture and mould levels in different building components. Mould samples were taken in 17 cold attics built between 1960-1965 and graded according to a 5 step scale (0-4) from "no mould growth" to "heavy growth over more or less the entire surface", [2]. The conclusions from the mould samples were that no correlation between insulation level on the attic floor and mould growth was found but that there was a tentative correlation between mould growth and leakage areas between living space and attic as well as reduced ambient ventilation by blocking the eaves, see figure 2 . The purpose of the study presented here was to investigate how well the MRD-model (Mould Resistance Design) could predict mould growth in roof structures within long periods of time. Three of the cold attics mentioned above were investigated.

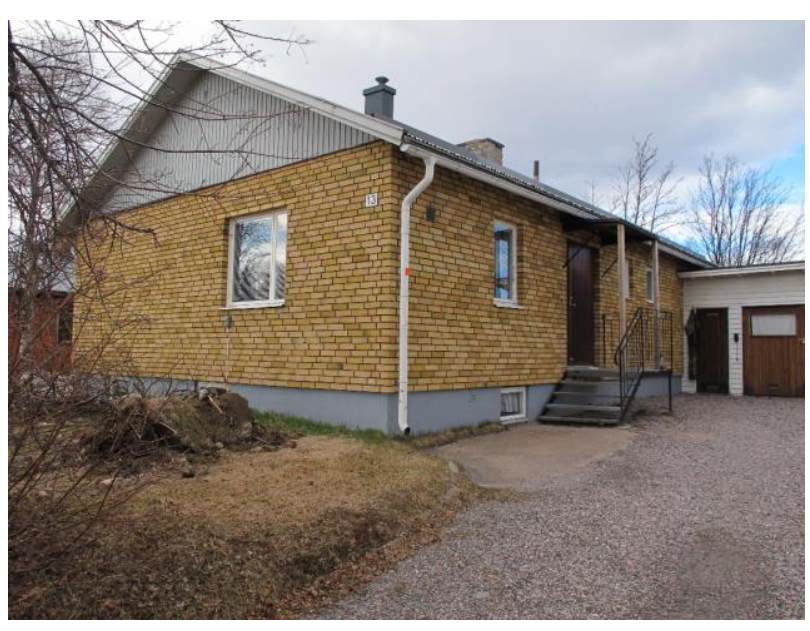

Fig. 1. Example of house in Malmberget (photo by author)

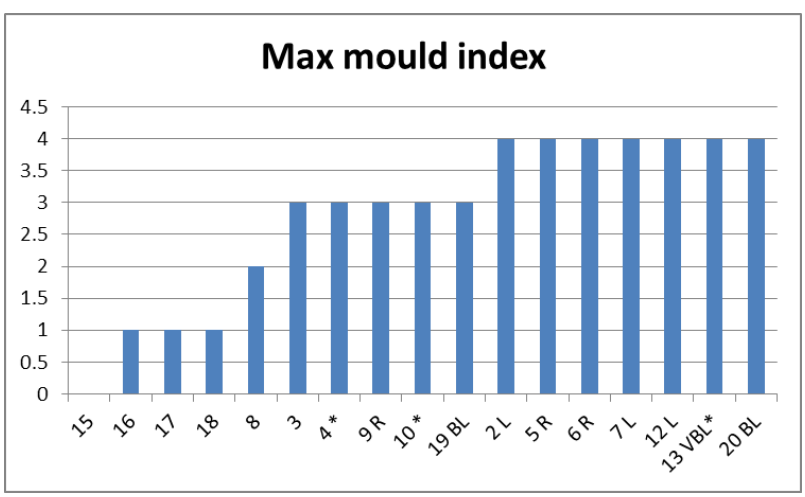

Fig. 2. Maximal mould index in 17 attics in Malmberget measured 2011 and 2012. $\mathrm{R}=$ reduced ambient ventilation, $\mathrm{L}=$ leakage from living space, $\mathrm{BL}=$ big leakage, $\mathrm{VBL}=$ very big leakage , * = attics simulated in this study. 


\section{Methods}

Samples of surface wood were taken at three locations in the structures: joists in the floor, rafters and wood roof (and battens when applicable) during the winters 20112012, see figures 3 and 4 . These samples were analysed with microscope to measure a mould index from 0 to 4 by Sanne Johansson at Lund University, Dep. Of Building Materials according to the method specified in by P. Johansson [6]. Three attics (nr 4, 10 and 13) were chosen for a more detailed investigation using the heat and moisture transfer program WUFI 6 Pro [7] which is a common program to calculate heat and moisture transfer in building envelopes. The mould indexes for these three attics are shown in table 1 . To be able to simulate the attics, a climate file for the period 1961 - 2012 was constructed and used as boundary condition for the simulation. Figure 5 shows the temperature and relative humidity the last 25 years. Figure 6 shows the mould index for the same period. Important parameters that were investigated were e.g.: ventilation in attic, air leakage from inside (living space), moisture load due to air leakage, position of this leakage in the structure (insulation or air space).The output from the simulations were then used in the MRD model to produce mould indexes for the period. The mould index was investigated at positions $\mathrm{A}, \mathrm{B}$ and $\mathrm{C}$ in figure 7 roughly corresponding to roof, rafters and joists.

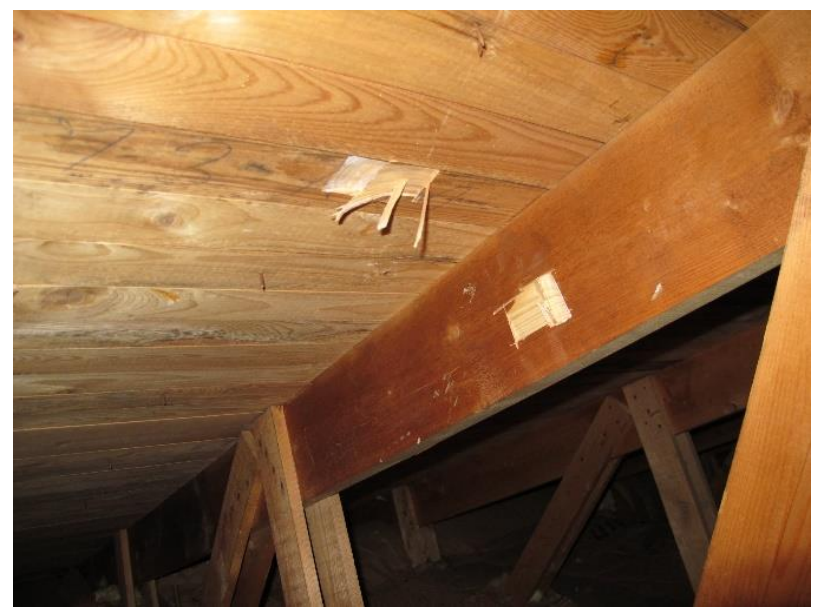

Fig.3. Wood samples for mould analysis from wood roof and rafter (photo by author).

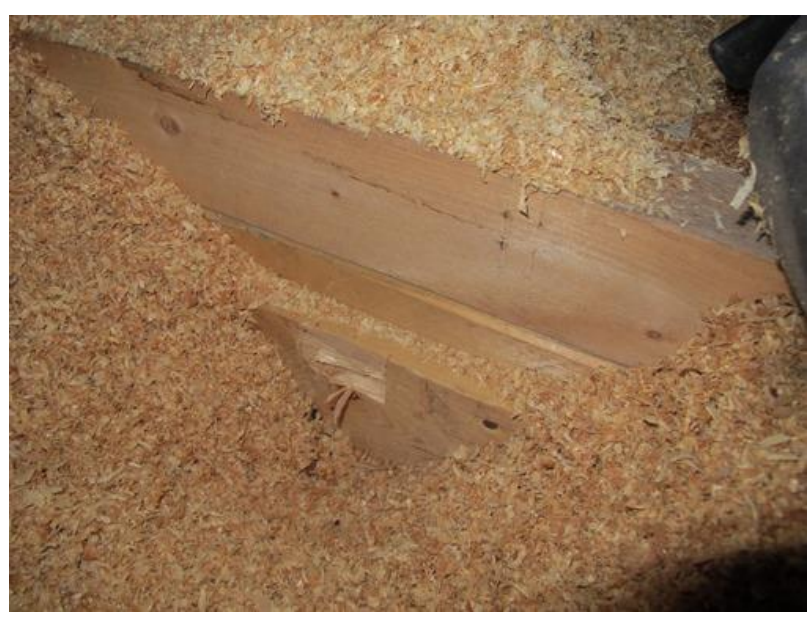

Fig.4. Wood samples for mould analysis from floor joist (photo by author).

Table 1. Measured mould index in attic 4,10 and 13 .

\begin{tabular}{|l|l|l|l|l|l|l|}
\hline \multirow{2}{*}{$\mathrm{Nr}$} & \multirow{2}{*}{$\begin{array}{l}\text { Total } \\
\text { Insul. } \\
(\mathrm{cm})\end{array}$} & $\begin{array}{l}\text { Mould Index } \\
\text { roof. }\end{array}$ & Battens & Rafter & $\begin{array}{l}\text { Floor } \\
\text { joist }\end{array}$ & Other \\
\hline 4 & 14 & & & 3 & 3 & \\
\hline 10 & 20 & & 3 & 2 & 2 & \\
\hline 13 & 15 & 4 & & 2 & & 4 \\
\hline
\end{tabular}

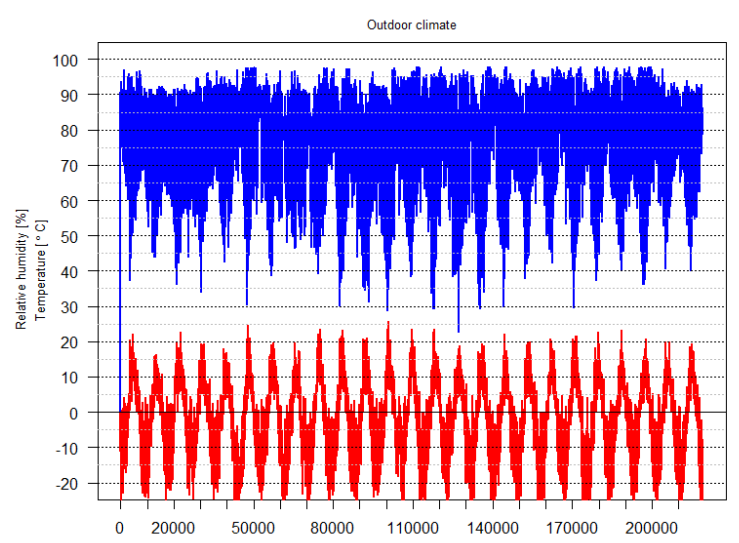

Fig. 5. Measured outdoor climate in Gällivare 19872012 . 


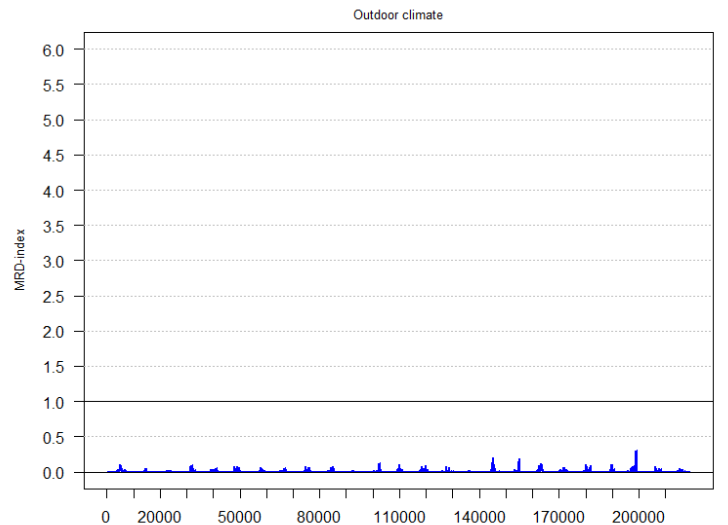

Fig. 6. Mould index for the outdoor climate in Malmberget/Gällivare 1987-2012.

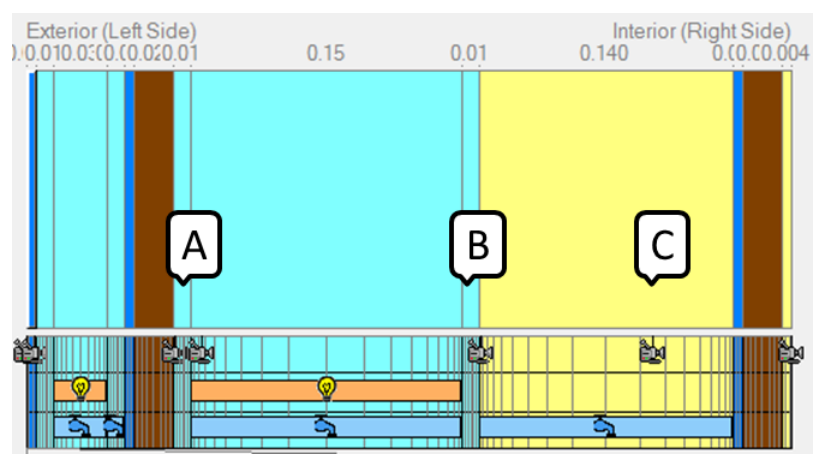

Fig. 7. WUFI simulation model for attic $\mathrm{nr} 4$ showing the measuring points. $\mathrm{A}=$ rafters/wood roof, $\mathrm{B}=$ rafters/floor joists, $\mathrm{C}=$ floor joists

\section{Results}

The maximal measured mould index for the attics varied between 0 and 4 . Figure 8 shows a simulation of attic 10 with moisture load in the airspace as an example of that the results were in the vicinity of the measured results. It was also found that it was not necessary to simulate the full period (1961-2012). Half of the period (the last 25 years) was enough. Of the possible parameters that could affect the MRD-index the most important ones in this investigation were:

- Air leakage at $50 \mathrm{~Pa}\left(0.3-2 \mathrm{l} / \mathrm{s} \mathrm{m}^{2}\right)$

-Moisture load in the living space, here chosen to 2 $\mathrm{g} / \mathrm{m}^{3}$

-Position of moisture source in attic due to air leakage from inside (in attic floor insulation or in ventilated air space close to roof).

-Ventilation in attic (5-15 airch/h).

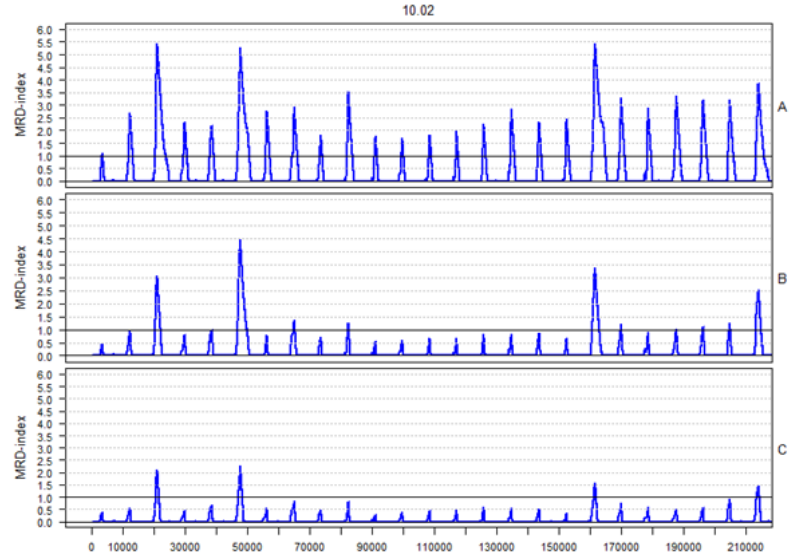

Fig. 8. Mould index for attic $\mathrm{nr} 10$ with ventilation $=7.5$ airch $/ \mathrm{h}$, air leak $=1 \mathrm{l} / \mathrm{s} \mathrm{m}^{2}$ at $50 \mathrm{~Pa}$ and moisture load= $11500 \mathrm{~g} / \mathrm{m}^{2}$ year over oct to April and placed in the ventilated air space in the attic. The simulation is between 1986-2011, x-axis in hours.

The attic with a large opening between living space and attic had the highest measure mould growth (4 in two positions). The simulations confirmed this (assuming a leakage of $\mathrm{q}_{50}=2 \mathrm{l} / \mathrm{s} \mathrm{m}^{2}$, see figure 3. From figures 8 and 9 it is clear that the simulation indicated more mould in the wood roof than in the floor joists. This was however not observed from the measurements where the floor joists in many cases had more mould than the other measured positions.

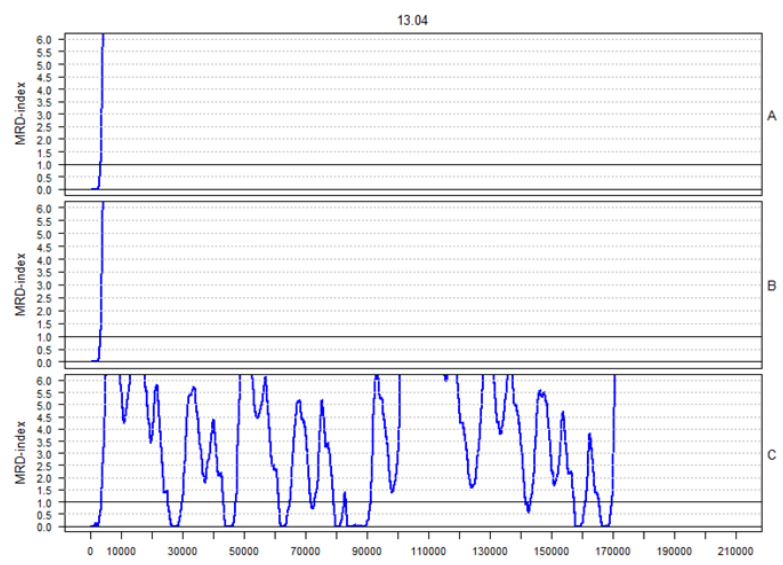

Fig. 9. Mould index for attic $\mathrm{nr} 13$ with ventilation $=10$ airch $/ \mathrm{h}$, air leak=2 1/s m${ }^{2}$ at $50 \mathrm{~Pa}$ and moisture load= $23000 \mathrm{~g} / \mathrm{m}^{2}$ year over oct to April and placed in the ventilated air space in the attic. The simulation is between 1986-2011, $\mathrm{x}$-axis in hours. 


\section{Discussion}

The method presented in [6] for measuring the mould index, was used when the MRD mould index was developed [3]. This means that the methodology used in the study presented here was a very reasonable choice. But the boundary conditions when the MRD model was developed, were used a much shorter time for the test materials, and with less varying temperature and relative humidity. This means that the study presented here goes beyond the parameter intervals used when the MRD model was developed. But the reason for developing a mould model is to be able to use it in a real scenario and that is why this study was performed.

There were many uncertain parameters in the study, the 25 years were based on measurements but had to be adjusted for periods when the data was not complete, the choice of where the moisture source was placed was a realistic but uncertain choice, the ventilation rate was clearly an educated guess at best, the leakage was also very roughly estimated. This means that the study was not a validation attempt but a test to see if measurements of mould on wood exposed for a very long time could be reproduced by simulations.

\section{Conclusions}

Comparing the measurements and the results from the simulations using the MRD-model showed great differences regarding the mould growth depending on the simplifications used in the WUFI model. Of critical importance was the choice of leakage simulation and especially where the moisture from the leakage was placed in the construction. The measurements were clearly showing mould growth and this was also simulated for a chosen set of parameters. From the presented study the MRD model can not be fully validated but it is clear that the model can produce realistic data given a certain set of realistic parameters.

We acknowledge LKAB Fastigheter and Kirunabostäder.

\section{References}

1. J. Arfvidsson,H. Bagge,L.-E. Harderup, D. Johansson, J.Stein and P. Wallentén, Tillståndsbedömning av byggnader med hjälp av förstörande provning av byggnadskomponenterkopplingar till brukarens hälsa och upplevd innemiljö ( Condition assessment of buildings by destructive testing of building components in connection to health and experienced indoor environment), ISRN LUTVDG/TVBH-13/7236-SE(79), Dep. Of Building Physics, Lund University, Sweden. (in Swedish) (2013)
2. D. Johansson, H. Bagge, J. Stein, J Arfvidsson, P. Wallentén and L.-E. Harderup, Building Performance Investigation in the Arctic by Help of Destructive Testing in Buildings - A Pilot Study, Seventh International Cold ClimateHVAC Conference, ASHRAE (2012)

3. S. Thelandersson and T. Isaksson, Mould resistance design (MRD) model for evaluation of risk formicrobial growth under varying climate conditions, Building and Environment 65, 18-25. (2013)

4. K. Gradecia, N. Labonnoteb, J. Köhlera, and B. Time, Mould Models Applicable to Wood-Based Materials - A Generic Framework, 11th Nordic Symposium on Building Physics, NSB2017, 11-14 June 2017, Trondheim, Norway, Energy Procedia 132, 177-182, (2017)

5. P. Johansson, Determination of the Critical Moisture Level for Mould Growth on Building Materials, PhD-thesis, Building Physics, Lund University, Sweden (2014)

6. A. Holm and H. M. Künzel, Non-Isothermal Moisture Transfer in Porous Building Materials, Materialsweek (2000) 